\title{
Weight gain a risk factor for mortality in patients with acute kidney injury requiring continuous renal replacement therapy
}

\author{
C Maldonado Toral ${ }^{1 *}$, L Dono $^{1}$, A Parra ${ }^{1}$, N Ramos$^{2}$, R Albertos $^{1}$, E Papiol $^{1}$, M Pérez $^{1}$ \\ From ESICM LIVES 2015 \\ Berlin, Germany. 3-7 October 2015
}

\section{Introduction}

Renal failure is one of the most common complications in critically ill patients, with a progressive increase in the need of renal replacement therapy (RRT). As wellknow the timing is pretty related with the improvement and outcome. But also the treatment dose and filter lifespan are variables that interfere in the results.

\section{Objectives}

Assess the prescribed treatment and the difference with the treatment achieved. Also evaluate the variation on vasoactive drugs and the weight impact on mortality rate.

\section{Methods \\ A retrospective descriptive study was performed during 14 months, between January 2014 and February 2015. All patients required Intensive Care Unit (ICU) admis- sion and RRT regardless of the pathology that led them in to the ICU. Demographic, clinical and biochemical data was recorded at the day of the admission and at the beginning of RRT. Data are reported as frequency (percentage) and median (interquartile range). Statistical test used were Pearson's test or Fisher test, U de Mann- Whitney test and logistic regression.}

\section{Results}

One hundred eighty nine patients were admitted in ICU during study period, sixty one of them required RRT, $64.5 \%$ male, median age was 64(54-60) years and body mass index 28(23-34). At the ICU admission, APACHE II and SOFA score were 34(26-38) and 11(9-13), respectively.

${ }^{1}$ Hospital Universitari Vall d'Hebron, Critical Care, Barcelona, Spain Full list of author information is available at the end of the article
Renal failure etiology was multifactorial cause $54.8 \%$, septic $29 \%$ and ischemia $4.9 \%$. Most of patients required mechanical ventilation $(84.7 \%)$ and vasoactive drugs (91.8\%).

More than half of RRT were initiated in the first 24h. Treatment dose prescribed during first three days of RRT were $32(25-40) \mathrm{ml} / \mathrm{kg} / \mathrm{h}, 32(25-35) \mathrm{ml} / \mathrm{kg} / \mathrm{h}$ and $25(20-34) \mathrm{ml} / \mathrm{kg} / \mathrm{h}$. However treatment actually achieved was a $4 \%$ less. At the beginning of RRT, median vasoactive drugs (noradrenaline) was $0.7(0.17-1.35) \mathrm{mcg} / \mathrm{kg} / \mathrm{min}$ and median creatinine $2.38(1.57-3.69) \mathrm{mg} / \mathrm{dL}$, decreasing $48 \mathrm{~h}$ later to $0.37(0.15-0.76) \mathrm{mcg} / \mathrm{kg} / \mathrm{min}$ and $1.50(1.11$ 1.96) $\mathrm{mg} / \mathrm{dL}$.

Median ICU LOS was 12(4-29) days with median RRT $4(1-6)$ days and overall mortality rate of $63.3 \%$. An increase more than $5 \%$ in weight during the first 48 hours of RRT was associated with increased mortality. In addition, SOFA score showed to be a good predictor of mortality at ICU admission and during the first 48 hours of RRT $(\mathrm{p}<0.01)$.

\section{Conclusions}

Patients with RRT present a high mortality. A weight gain during first $48 \mathrm{~h}$ of RRT has been related to increase mortality rate. Furthermore it has been shown a reduction in the vasoactive drugs.

\section{Authors' details}

${ }^{1}$ Hospital Universitari Vall d'Hebron, Critical Care, Barcelona, Spain. ${ }^{2}$ Hospital Universitari Vall d'Hebron, Nephrology, Barcelona, Spain.

\section{Published: 1 October 2015}

\section{References}

1. Bagshaw S, Uchino S, Kellum JA, Morimatsu H, Morgera S, Schetz M, et al: Association between renal replacement therapy in critically ill patients

\section{SpringerOpen ${ }^{\circ}$}

(C) 2015 Maldonado Toral et al.; This is an Open Access article distributed under the terms of the Creative Commons Attribution License (http://creativecommons.org/licenses/by/4.0), which permits unrestricted use, distribution, and reproduction in any medium, provided the original work is properly cited. 
with severe acute kidney injury and mortality. J Crit Care 2013,

28(6):1011-1018

2. Fülöp T, Pathak MB, Schmidt DW, Lengvárszky Z, Juncos JP, Lebrun CJ, et al: Volume-Related Weight Gain and Subsequent Mortality in Acute Renal Failure Patients Treated with Continuous Renal Replacement Therapy. ASAIO J 2010, 56(4):333-337.

doi:10.1186/2197-425X-3-S1-A466

Cite this article as: Maldonado Toral et al: Weight gain a risk factor for mortality in patients with acute kidney injury requiring continuous renal replacement therapy. Intensive Care Medicine Experimental 2015 3(Suppl 1):A466.

\section{Submit your manuscript to a SpringerOpen ${ }^{\mathcal{O}}$ journal and benefit from:}

- Convenient online submission

- Rigorous peer review

- Immediate publication on acceptance

- Open access: articles freely available online

- High visibility within the field

- Retaining the copyright to your article

Submit your next manuscript at $\gg$ springeropen.com 